\title{
European Developments in Business Anthropology
}

\author{
Alfons van Marrewijk \\ VU University Amsterdam
}

\begin{abstract}
American anthropologists and practitioners have dominated the debate on organization culture for a long time. European business anthropologists have not been very visible to American scholars because they publish irregularly in American academic journals and generally use their national languages; French, German, Swedish, Dutch and Danish. Business anthropologists in the UK, the Netherlands, Sweden, Norway, Denmark, France, Italy and other European countries have dedicated their time and energy to study corporations but not to organize themselves in a network. This paper explores the European development of dissident business anthropologists criticizing the dominant concept of culture and used methodology in mainstream organization studies. Business anthropology in the different fields of management of diversity, cultural change, cross-cultural cooperation, organization culture, and organizational ethnography is well alive in Europe.
\end{abstract}

\section{INTRODUCTION}

Although the comprehensive study of the history of business anthropology has not yet been written, there is a fairly large amount of survey articles dealing with the topic (Baba, 1986; Baba, 2001; Bate 1997; Fine, et al., 2008; Holzberg and Giovannini, 1981; Jordan, 1994; Jordan, 2003; Schwartzman, 1993). These contributions distinguish four different phases in the development of business anthropology. The first phase is situated in the early 1930s when Elton Mayo contracted anthropologist Lloyd Warner to systematically observe the behavior of employees in the Hawthorne studies. The second phase concentrates on the period after World War II when interests emerged in organization culture (Schwartzman, 1993). In this period, the first consultancy firm using anthropological methods started (Baba, 1986). However, there was no real break-through in the interest of anthropologists for studying organizations. The third period named in the literature is the era including the 1960s and 1970s. Traditional anthropological fieldwork in 'exotic' conflict areas, such as Vietnam and Latin America, flourished again due to governmental financial support. Resulting from the political nature of the anthropological assignments, ethical dilemmas emerged. Consequently, anthropology and clients were driven apart in this third period.

The fourth and most recent epoch started in the early 1980s when business organizations and anthropologists regained interests in each other. In 1983, the University of California organized 
the first conference on organizational culture and the Administrative Science Quarterly published the first special issue on the topic. With Peters and Waterman's (1982) discovery that organizational culture is a factor in attaining excellence, this topic was catapulted to the top of the corporate agenda. It turned out that successful organizations were not those touting hefty folders of formalized regulations, but those that valued leadership and decentralized influence while emphasizing norms and values (Peters and Waterman 1982). This work and work of Deal and Kenney (1988) and Schein (1985) all attracted the attention of corporate managers and business anthropologists. For them, organizational culture has been one of the main themes over almost 30 years now.

Clearly, American anthropologists and practitioners have dominated the debate on organization culture. American scholars, in cooperation with the National Association for the Practice of Anthropology (NAPA), published a number of books on business anthropology and consultancy (Giovannini and Rosansky 1990), on business anthropology and biographies (Jordan, 1994) and on the historical development of business anthropology (Baba, 2001). Furthermore, American corporations increasingly hired anthropologists to design new technology, to learn to know their customers and to improve their business (Corbett, 2008; Davenport, 2007; Gruener, 2004; Miller, 2005). Consequently, Davenport claims the success of business anthropologists in the Harvard Business Review;

'I have been predicting for years that anthropologists would soon be in demand in the workplace, and now this is finally coming to pass' (Davenport, 2007, p.2)

One would easily forget developments in other parts of the world. Business anthropologists in the UK, the Netherlands, Sweden, Norway, Denmark, France, Italy and other European countries have dedicated their time and energy to study corporations. In Britain for example, shop floor studies by Manchester anthropologists in the 1950's and 1960's have been important in the development of business anthropology (Wright, 1994). However, European business anthropologists have not been very visible to American scholars. Not only because they have not published regularly in American academic journals, but frequently, they publish their work in national languages; French, German, Swedish, Dutch and Danish (see Chanlat, 1994a; Hannerz, 2010). Another reason for the invisibility is the weak organization of business anthropologists in Europe. The website of the European Association of Social Anthropologists for example, does not recognize 'business anthropology' or 'organizational anthropology'. There is no established permanent network of scholars from all over Europe to co-operate on the field of business or organizational anthropology. Therefore, it will be difficult here to present an extensive overview of all developments over the last thirty years in European business anthropology. However, this chapter aims to explore some of these developments. To do so, I first discuss the different labels used in Europe concerning anthropologists' research activities in organizations.

\section{BUSINESS ANTHROPOLOGY OR ORGANIZATIONAL ANTHROPOLOGY?}

Research activities of European business anthropologists are labeled organizational ethnography, organizational anthropology, business anthropology or industrial anthropology. The four labels are partly overlapping and frequently mixed up. For example, the labels organizational anthropology and business anthropology regularly get confused. The label business anthropology, which refers to the applying of anthropological theories and methods to 
improve corporate functioning (Baba, 1986; Serrie, 1984), is not widely used in Europe. The label organizational anthropology is far more used. This label refers in Europe to the broad field of both applied anthropology in organizations and the academic anthropology of profit, and not for profit organizations and networks. Organizational anthropology is understood as a multidisciplinary approach with anthropology as the lens through which organizational culture is viewed as a process of sense making (Dahles, 2004, p. 24).

Not only organizational anthropology and business anthropology but organizational anthropology and organizational ethnography too are frequently mixed up. Organizational ethnography is the ethnographic study and its dissemination of organizations and their organizing processes (Ybema et al., 2009, p.4). Although ethnography is the organizational anthropologist's most important method (Bate, 1997), it is not their exclusive domain. Scholars in organization studies, with other than anthropological disciplinary backgrounds, have increasingly picked up ethnographic methods. This is shown by Yanow and Gueijen (2009) who present a bibliography of organizational ethnographies based upon a threefold criteria; methods (ethnography), writing (narrative) and sensibility. These selection criteria only include studies that focus on topics generally studied in organizational studies and situated in an organizational context. Not all organizational anthropologic studies fit these criteria. Consequently, organization anthropology and organization ethnography are overlapping fields. Finally, the label industrial anthropology, understood by Baba (1986) as the academic study of industrial organizations for the fundamental understanding of its functioning, is hardly used in Europe.

In this contribution, I use business anthropology to emphasize the close relation with organizations in developing knowledge. In fact, business anthropology has always developed itself in close interaction with corporations resulting in important scientific contributions (Baba, 1986). Although getting access in business organizations is not easy in Europe, executing academic research is easier than in the United States due to relaxed company and national regulations.

\section{EARLY DEVELOPMENTS IN EUROPEAN BUSINESS ANTHROPOLOGY}

The increased attention for organizational culture in the early 1980s triggered the attention of anthropologists throughout Europe. In the institutional context of European universities business anthropology related to traditional anthropology with a certain tension. This relationship between a traditional discipline and a new specialization is not exactly unique. In the United States, the cultural approach to organizations too, is often the work of business school researchers rather than academic institutions. This is a logical development in terms of resistance to change, the struggle for scarce resources and cultural clashes in organizations. Because of this, unfortunately, the network of organizational anthropology practitioners in Europe is only a small, dissident community amidst a wide circle of authors in business administration, organizational sciences, sociology, and psychology. They are part of a larger network of organizational scientists who study organizational culture from an interpretative perspective (Czarniawska, 1992; Watson, 1994; Weick, 1995).

Early business anthropologists in the dissident community were, among others; Paul Bate, Susan Wright and Martin Parker in the UK, Hans Tennekes and Willem Koot in the Netherlands, Bruno Latour in France, Brain Moeran in Denmark, Ulf Hannerz in Sweden, Carla DahlJørgensen in Norway and Dipak Pant, Alberti Fernando and Pasquale Gagliardi in Italy. These scientists all worked in different institutional contexts with different anthropological traditions. 
In Britain, for example, the emphasis of anthropologists was, until the 1990s, on social anthropology and actual social relations (Wright 1994). British anthropologists generally referred to material artifacts and dramatic performances when discussing the concept of culture. Notwithstanding this tradition, some British anthropologists turned their interests towards organizational culture. Malcolm Chapman for example, writes how he turned his interests from studying Celtic fisher's villages to business organizations in the early 1990s (Chapman, 2001). In other countries, such as the Netherlands, business anthropology developed as an independent specialization of the anthropology discipline.

\section{DEVELOPMENTS IN THE NETHERLANDS ${ }^{1}$}

In the Netherlands, cultural anthropologists Tennekes $(1994 ; 1995)$ and Koot $(1989 ; 1995$; 1994; 1996) have done pioneering work to position business anthropology in organization studies. In 1989, Tennekes launched a university study program called Culture, Organization and Management at the VU University Amsterdam which soon attracted hundreds of students. With publications in Dutch such as 'Mythen over corporate culture' ['Myths of corporate culture'] (Koot, et al., 1989) and 'Totems en Stropdassen' ['Totems and ties'] (Koot, 1989) Koot and Tennekes established themselves as one of the main founders of the field of Dutch organizational anthropology (Van Marrewijk and Verweel, 2005). In 1989, the year when Koot published his critical examination of the myths of corporate culture, a number of anthropologists for the first time explored the possibility of a program to analyze organizations from an anthropological perspective. The discussion appeared in the Dutch journal 'Antropologische verkenningen' ['Anthropological Explorations'].

In 1994, Hans Tennekes established the first full professorship of Organizational Anthropology in the Netherlands, a chair which fell to Willem Koot. At the University of Utrecht, organizational anthropology took root in the chairs of Paul Verweel (1999) and Arie De Ruijter (1982; 2004). In Amsterdam, Koot was succeeded by Heidi Dahles (2003), holding the chair in Organizational Anthropology, especially the Ethnography of Organizations, and by Marcel Veenswijk (2004) holding the chair of Management of Cultural Change in Complex Organizations. In 2009, Alfons van Marrewijk was appointed to the extraordinary chair in Business Anthropology. In both Amsterdam and Utrecht, organizational anthropology is firmly anchored with its own influx of students and an accredited research program. In the meantime, various people have attained doctors' degrees in this field of study (e.g. Dobbinga, 2000; Sabelis, 2002; Van Marrewijk, 1999; Wels, 2000; Ybema, 2003). Moreover, hundreds of students have entered the job market as qualified organizational anthropologists. Both university groups maintain close ties in research, which ensures that organizational anthropology will remain institutionally well-embedded.

\section{CONTRIBUTIONS OF ANTHROPOLOGISTS}

Apart from Dutch anthropologists, other European anthropologists have contributed to the development of business anthropology. For an excellent overview of the development of organizational culture studies in the UK see Martin Parker's (2000). For example, Susan Wright's book Anthropology of Organizations (1994) very much helped to develop the anthropological approach of organizational culture. In this edited book, business anthropologists such as Thris Nicolson explore anthropological concepts of indigenous management to criticize 
mainstream studies on organizational culture. Nicolson (1994), studied the functioning of public management in Papua New Guinea and found that the phenomenon of wantok, a complex system of mutual obligations, played an important role in the functioning of public service. In fact, wantok rules were incompatible to the rules of the governmental bureaucracy. The setting up of district managers provided a mechanism for greater community participation while at the same time institutional building could progress (Nicholson, 1994). Apart from such indigenous management examples, contributors to the book studied cases such as the British welfare benefits system, a trade union, a hospital, a housing aid office and gender in offices.

Other examples of UK contributions are Paul Bate's book Strategies for Cultural Change (1994) and his article What ever happened to Organizational Anthropology (1997), which have both been influential in the development of business anthropology. In his book, Bate (1994) took a strong position against mainstream strategy research claiming that strategic change and cultural change are two independent aspects of organizational change. He successfully argued that strategic change is similar to cultural change. Furthermore, in his widely cited 1997 article, he claims a distinct position of the anthropological perspective on organizations against other organizational perspectives. Bate sees (1997) three unique characteristics of organizational anthropology: (1) the method of fieldwork activity, (2) the paradigm and (3) the narrative style. Firstly, the major invention of anthropology is the method or the 'doing' of ethnographic fieldwork by means of participant observation. Bate views fieldwork and especially the attitude of 'suck and see' as a major characteristic of anthropological organization research, although he criticizes the 'mystique' attitude of some anthropologists making this methodology very fussy. He emphasized that 'insight always comes from the inside' (Bate, 1997, p. 1161). Secondly, the paradigm or 'thinking' of anthropologists concerns looking critically at organizations and perceiving organizations as a cultural phenomenon. An organization is a modern 'tribe' with its own cultural values and norms that prescribe the behavior of employees. Finally, the narrative style, or "writing" of ethnographies by anthropologists distinguish organizational anthropology from others in organizational science in that it can be poetical, fictional, autobiographical and postmodern (Bate, 1997). The anthropologist can be seen as a performer that has to combine arts, science and craft in order to write ethnography. Bate concludes 'that commitment must also stretch to experimentation with different styles' (Bate, 1997, p. 1154).

In Italy, distinct business anthropologists have contributed to a better understanding of what anthropology can contribute to mainstream organization studies. The important book Symbols and artifacts edited by Pasqual Gagliardi (1990), explored the much neglected material and symbolic aspects of organizational culture. Berg and Kreiner, for example, explained in their contribution that corporate buildings are seldom left to speak for themselves; they are described, reviewed and interpreted over and over in discourses in organisations (Berg and Kreiner, 1990, p.62). In this way, corporate headquarters are aesthetic and symbolic representations of organisational change goals and have become symbols of corporate change ambitions to endure cultural value sets. Gagliardi's book has influenced and enriched mainstream organisation science. Other Italian anthropologists, Pant and Alberti (1997), explored in their article Anthropology and business: reflections on the business applications of cultural anthropology the strongholds of anthropology and possible fields to apply anthropological knowledge.

In France, Jean Francois Chanlat (1994a) demonstrates how French analysis of organizations has evolved and remains distinct from American mainstream analysis. He gives an interesting overview of the contributions of French organization scientists, who generally publish in French. An exception to this is Chanlat himself, who published Towards an anthropology of 
organizations (1994b) in which he explores the multiple layers of culture in organizations. Of course, French anthropologist and philosopher Bruno Latour needs no introduction and has been influential to science in general, and to business anthropology in particular. He influenced business anthropology with his ethnographic work on the everyday life in a laboratory describing the production of scientific knowledge (Latour, 1987). Moreover, Latour (1993) utilizes anthropological theories of pre-modern societies to suggest a symmetric anthropology of modern society. He introduces the concept of symmetric anthropology as a way of making equally problematic the world of people and the world of material phenomena, as well as their intersections and entanglements in social-material hybrids. These worlds of human and nonhumans were separated as two irrevocably sundered realms of knowledge and experience during the period of the Enlightenment. Such a separation imposes a binary division on the world of human experience that is not itself in the world.

Other contributions were from Swedish anthropologist Ulf Hannerz (1992) who influenced business anthropologists with his book Cultural Complexity: Studies in the Social Organization of Meaning. These are only a few of the contributions, which helped to further develop business anthropology in Europe. Of course, American and European social scientists such as Van Maanen, Czarniawska, Weick, Bourdieu, Baumann, Smircich, Martin and Schein have been important points of reference for European business anthropologists.

\section{CRITICIZING DOMINANT CONCEPTS OF CULTURE}

Anthropologists criticizing the dominant concept of culture in mainstream organization studies have been important in the early development of business anthropology in Europe. In the 1980s mainstream theoreticians and practitioners mainly took unity of culture and therefore the directive, normative function of culture as their point of departure (see Deal and Kennedy, 1988; Hofstede, 1980; Peters and Waterman, 1982). Especially the work of Dutch anthropologisteconomist Geert Hofstede (1980; 1986), Sanders and Neuijen (1989) and later, Trompenaars (1993), on organizational culture and intercultural management triggering anthropologists to criticize the integrative perspective on culture (e.g. Koot, 1995). In this debate, the multiple dimensional value model of Geert Hofstede has been dominated in both academic journals and business organizations (Morden, 1999).

Dutch business anthropologists praised Hofstede's and Trompenaars' theories for their attention to national culture. Indeed, national cultural maps (f.e. Hofstede, 1980; Trompenaars, 1993) have helped organizations to understand the reasons behind cultural differences among countries and to realize how an understanding of these differences is crucial in order to know what is appropriate management behavior with regard to specific cultural contexts (Lowe, 2002). However, the maps were also fiercely criticized for their scant attention to differences within culture and the static character of their cultural analyses (Koot, 1995; Verweel, 1989). According to business anthropologists, the common concept of culture was too static; as if it were an unambiguously specifiable collective programming of people in an organization (Koot and Hogema, 1990; Verweel, 1989; Wright, 1994).

Inspiration for criticizing the mainstream concept of culture came from Barth's studies. Barth (1969) points out that culture should be viewed and analyzed as dynamic, strategic, and situational. Barth (1969) showed that the culture of groups should not be understood through the identification and description of objective criteria. His research had taught him how influential people's specific, changing context is. He had found that, depending on context, people 
emphasize and use their cultural characteristics in various ways for strategic reasons. One important mechanism is the fluidity with which such groups defined 'us and them' boundaries and presumed differences, as well as the importance of such differences. Therefore it is key to maintain a situational approach with an eye for the processes whereby boundaries are set and qualities are ascribed - both to different groups within an organization and to other organizations. 'Publicly upheld and shared norms and values may in reality not be present as they are assumed to be,' argued Koot (1989: 42). Therefore, business anthropologists take the position that besides normative attempts to interpret culture as monolithic, there is an empirical reality of diversity of groups and fragmentation of views. Here, reference is to the tendency to trivialize cultural difference and/or the attempt to gloss over any cultural differences as quickly as possible. It is often assumed that time helps to integrate cultures. With a measure of clairvoyance, however, fear and a sense of threat are the driving force behind the upgrading and reinforcing of traditional cultural differences (Koot and Hogema, 1990, p.169).

The critics on Hofstede's and Trompenaars' multi value models can be summarized as follows (Koot, 1997; Van Marrewijk, 1999);

- A rather over-simplified and static perspective on the handling of cultural differences;

- A singular focus on nation-state cultures;

- Focus on differences rather then similarities amongst people;

- Pointing out the otherness of others is said to increase stereotyping and resentment towards the Other;

- A disputable assumption that cultural differences are stable, and measurable;

- The absence of power issues and situational use of cultural differences;

- The assumption that cultural differences can be overcome.

In sum, business anthropologists in the Netherlands as well as other European countries criticized the dominant cultural paradigm in organizational studies and argued that a situational and strategic perspective of culture enables effective managers to detect what leadership style works in a given culture and develop the necessary skills in order to work with this required leadership style.

\section{CRITICIZING METHODOLOGY}

Apart from the concept of culture, European business anthropologists also criticized the methodological standards used in mainstream organization culture studies. The tools used, such as pre-programmed questionnaires, were too general to do justice to the complex phenomenon of cultural dynamics. According to the business anthropologists, the focus should be on:

Understanding organizational mechanisms underlying daily interactions of people both on the work floor and in management. (Koot, 1994, p.109)

Prevailing theoretical approaches taken by organizational researchers is deficient in an anthropological sense. In many cases, culture is regarded as an aspect of organization, obscuring its relationship to other aspects such as strategy and historical and social context. This approach fails to explore the power of individuals and the balance of power between people. For an indepth understanding of organizational processes, daily practices should be studied. These 
insights show that, apart from the rational aspect of a goal-oriented organization, numerous interpersonal processes are important in the understanding of organizational culture. European business anthropologists advocated having an eye for the special, the informal, the codes, symbols and rituals, being critical of the desired and the current culture, analyzing the relationships behind the current culture and analyzing the discrepancies between narratives and practices. In sum, organization scholars have to learn to think culturally (Bate, 1994).

Business anthropologists believe that an anthropological formulation of theories offers a particularly good basis for exploring, putting into perspective and enriching the prevailing views on organizational culture. Moreover, a bottom-up approach results in important additional knowledge about an organizational culture. Therefore, true interests in people is needed.

Sometimes it seems as if curiosity, true curiosity about the core of the organization, about the way people function in it and the formal and informal sides of the project, recedes to the background. Seldom do we see the element of amazement and surprise one experience when encountering an unfamiliar situation. The ability to look on in wonder, however, is typical of the anthropologist. (Koot, 1989, p.5)

\section{FOCUS ON CULTURAL ANALYSIS OF ORGANIZATIONS}

Business anthropologists developed their interpretive perceptions on organizational culture in reaction to the integrative managerial concepts used in mainstream organization studies. From the mid-1990s onwards, the perspective of organizational anthropology, and the object of study in particular, broadened. Organizational anthropologists no longer analyzed success factors of organizational culture and corporate culture but their focus shifted to a cultural approach to study organizational issues. Therefore, in his inaugural speech entitled 'the complexity of everyday life: an anthropological perspective on organizations', Koot (1995) proposed the unraveling of cultural processes by studying everyday life in organizations. These everyday practices show the paradoxes, ambiguities, and frictions in the organizational culture. In such a cultural approach, respondents play an important role:

By engaging them in conversation about their everyday actions and the motives behind these deeds, a mirror is held up to them, and they can also see more clearly what is going on in their organization. (Koot, 1995, p.29)

Tennekes (1994; 1995) moved away from cultural characteristics towards a descriptive definition in which culture is interpreted as a coherent complex of meanings. Bate characterizes this complex as containing internal tensions, contradictions and ambiguities. He understands it as an open system in which, depending on the situation, new answers (meanings) are added and others are replaced. In this view, culture not only serves as a model of and for reality, but it also prescribes how to act, which values are worth pursuing and which alternative behaviors are at one's disposal (Tennekes, 1994).

Structure is the product of employee's intentional actions and, at the same time, a reality that can, to some extent, defy those intentions (Tennekes, 1995, p.25). These structures have different but interrelated analytical levels: national level, regional level, organizational level and subcultural level (Chanlat, 1994b). Bate remained skeptical of managers' capacity to unilaterally 
manipulate culture as a success factor. In his view, management literature exudes too much naive confidence that effectiveness and efficiency can be influenced from the managers' perspective. At the same time, he believed such literature does not sufficiently take the input of members of the organization, their clients, external stakeholders, and circumstances into account. The notion of deliberately influencing culture presupposes a broad analysis and a cohesion in the conceptions of different groups (Koot and Boessenkool, 1994; Tennekes, 1995).

The Dutch 1994-volume of 'Antropologische Verkenningen' shows a broadening of the object of study. The focus shifts from organizational culture as an isolated success factor to how organizations as a whole function in their social context. Moreover, that year's special issue also deals extensively with ethnic and international differences. Evidently, multi-culturalization and internationalization had gained a strong foothold as objects of study in organizational anthropology. The theoretical approach introduces a cultural vision that is apparently based on finding meanings of different actors in and around organizations. Culture in general and organizational culture in particular are to be regarded as a dynamic process in which strategic choices are made, different constructs of reality coexist, and therefore different structures and classifications are posited (e.g. us/them distinctions). Much more than in 1989, the journal focuses on the relationship between the balance of power and organizational cultures. The authors believe it is important to acknowledge that culture and dynamics within cultures are interwoven with the differences in power of different groups. Not everyone has an equal opportunity to express their definition of reality or to carry out their repertoire of actions. In addition, cultural context often defines which means of exercising power are important. Koot and Boessenkool summarize these views as follows:

\begin{abstract}
About culture, we can say that it is both rational and irrational; has formal and informal sides; has both a statically conservative and a highly dynamic and process-driven character; is used strategically and has a highly emotional and irrational charge; provides clarity by offering standard rules and solutions while remaining opaque; reflects unity, diversity and ambiguity; is homogeneous as well as heterogeneous. (Koot and Boessenkool, 1994, p.56)
\end{abstract}

\title{
MANAGEMENT OF MEANING AND MEANING OF MANAGEMENT
}

From such a point of view, organizational culture studies should focus on the actor's perspective and how actors give meaning to organizational events (Koot and Boessenkool, 1994, p.60). This inside perspective should be the guiding principle in order to guarantee reliability of research (ibid., p.61). They continue arguing that studies should not be aimed at producing generalizable research findings, but at analyzing local, complex definitions of reality in an arena of meanings and protocols. To gain such an insight into the everyday world of an organization's members, traditional anthropological research methods such as participation, observation and open-ended interviews are appropriate tools because formalized research strategies and preprogrammed questionnaires lack the flexibility to analyze the actors' definitions of reality. At best they impose definitions of reality on the actors and are therefore unreliable as measuring instruments (ibid., p.66-7). Moreover, these instruments fail to distinguish between protocol and actors' actual behavior.

The theory of organizational anthropology was further developed in a broad Dutch theoretical program focusing on the analysis of organizations' complexities. The joint research program 
entitled 'Management of meaning and the meaning of management', in which anthropologists from Utrecht and Amsterdam participated, reflected a number of the premises discussed above. In their views, social structures facilitate and limit actors' choices and strategies, but at the same time, these structures are the result of the actors' available actions, significations and resources. Furthermore, organizing and managing are seen as an intentional process of signification that should be understood as the outcome of a social and cultural process.

The Dutch business anthropology studies organizational and managerial processes which take place in a complex, layered and heterogeneous field in which a diversity of actors - whose access to resources is not equal - operate. In order to analyze this complexity, a multi-actor perspective is necessary. Against this background, both the intention to be effective and the presumed homogeneity of managerial and administrative interventions are viewed critically. The historical context in general and modernization processes in particular continue to be the subject of analysis related to organizational context and actors' actions in that particular context. Compared to the earlier focus, explicit attention is now paid to how processes in organizations are influenced by processes such as individualization, globalization, ICT and interculturalization of society, and vice versa.

\section{DIFFERENT ROLES OF ANTHROPOLOGISTS IN ORGANIZATIONS}

A clear and well defined image of the professional group of business anthropologists in Europe is hard to give because the discipline has become a multiple discipline (Dahles, 2004). Consequently, the diversity of roles in different fields is large (Cohen and Sarphatie, 2007; Jordan, 1994; Olila and Teunissen, 1989; Serrie, 1984). Cohen and Sarphatie explored the job opportunities of anthropologists in Dutch business organizations. They interviewed anthropologists in; the Foresight, Trends and People Research group of Philips, Dutch Railways, Trompenaars-Hampden-Turner Consulting, Pentascope, Berenschot and Twijnstra and Gudde (Cohen and Sarphatie, 2007). Their respondents worked as cross cultural trainers, organizational culture change consultant, intercultural specialist, interim manager, local market expert, international HRM, design anthropologist and marketer. Business anthropologists not only work in Dutch organizations but are generally found in European corporations such as Nokia and the London financial market (Corbett, 2008; De Ronde, 2009; Miller, 2005; Tett, 2005).

Unfortunately, the increase of the number of business anthropologists has not resulted in a well defined professional group. Consequently, business anthropologists cannot wait for employers with job advertisements but have to actively search for work. However, organizations still do not recognize the competencies of business anthropologists so anthropologists find it hard to sell their qualities. Anthropologists have learned to distance themselves from their own society without becoming a 'native' in the studied society. This 'in between' position facilitates the anthropologist to be a translator and 'bricoleur'. However, this uprooted position restrains them to fully take advantage (Lévi-Strauss, 1966).

When involved in a business organization, the organizational anthropologist is confronted with new roles, language, clothing, behavior, and informal networks. In the Netherlands therefore, the Non Academic Anthropologist working in different industries and organizations have organized themselves in a network. Participation in organizational life elicits a strong, emotional response that has an impact on research work (Kunda, 1992, p.273). In that environment, the academic anthropologist has to give up the status of the knowledgeable person. Czarniawska (1998) gives a personal account of losing her professional identity when doing field 
work and concludes that the threat of losing one's identity is the most painful aspect of field studies. She experienced feelings of 'being dumb' and 'continually running up against blank walls' (ibid., p.42). In many cases, business anthropologists are not well prepared to work in business organizations.

Although only a very small percentage of academic anthropologists join an academic carrier, academic curricula do not prepare anthropologists for a professional carrier in industry (Miller, 2005; Tett, 2005). Interestingly, the highly praised competences of anthropologists such as empathy, flexibility, local knowledge, speaking local languages, cultural sensitivity are absent when applying for industrial jobs. Anthropologists have difficulties to align their competences with the needs of industry (Cohen and Sarphatie, 2007) and in too many cases they are bypassed by economists, organization psychologists, and experts in public administration.

For business anthropologists however, becoming part of formal and informal organizational networks is an essential method in the study of an organization. Therefore, many business anthropologists combined advisory activities with research projects. Moreover, in the research process, collaboration between applied anthropologists and potential users increases the chance that findings will be used. Therefore, business anthropologists Olila and Teunissen (1989) see four different roles for business anthropologists in organizations. The first role is the intercultural specialist who supports the organization in questions of intercultural management. The second role is the 'parachutist' who intervenes in actual crises that need a quick solution. The third role is the expert of organizational cultures who diagnoses and discovers cultural strains. The fourth role is the expert in change management who designs and supports corporate strategies for cultural change. In line with these findings Schein (1985) recognizes differences between the roles of ethnographer and consultant. The ethnographer collects organizational data to academically understand the culture from an inner perspective. Whereas the consultant, who is hired by the company to investigate or solve a problem, uses a clinical perspective for data collecting through a quick scan or a limited number of interviews. Schein stresses that these different research perspectives result in a different relationship to the object of study and can therefore result in different findings. To combine the roles of ethnographer and consultant Van Marrewijk et. al (2010) introduces the role of the ethnoventionist. Here, the anthropologist uses ethnographic data to intervene in the organization's culture in order to change it.

\section{DIFFERENCES BETWEEN BUSINESS ANTHROPOLOGISTS AND ORGANIZATION ADVISORS}

Olila and Teunissen (1989) point out three differences between the business anthropologist and organization advisors. The first and most important difference is related to the question: 'whom are you working for?' The business anthropologist tends to work with employees on the work floor. In contrast, organization advisors rather work with the top management, which gives more status, clearer results and new commissions. The business anthropologist is interested in the emic or native view: the view of the employees. The business anthropologist can help management to understand cultural processes on the 'work-floor'. He or she is more capable of working on the 'work-floor' than the organization advisor who is inclined to adopt the management perspective:

Microstudies are more often than not on the side of the underdogs, be they managers or workers and, on the side of the rebellion. By showing how 
macropictures are drawn, microstudies problematize the taken for granted. (Czarniawska, 1998, p.49)

The second difference between business anthropologists and organization advisors is the time they need for research. While business anthropologists need two years to uncover and unravel the organizational culture, organization advisors do this in a much shorter period (e.g. Czarniawska, 1992, Bate, 1997). Not only the method of participant observation used by the business anthropologist, but also the historical, contextual and process based approach is very time-consuming. The study with its historical, process and contextual approach demands a great deal of time to implement (Bate, 1997). The study aims to be a 'true' ethnographical research with a long-term stay in the organization instead of what Bate (1997, p.1150) named a 'jet-plane' ethnography.

The third difference between business-anthropologists and organization consultants is located in the presentation of data. The business-anthropologist tends to include sensitive data in the presentation because of the commitment on the 'work floor'. This presentation concerns the difference of rule and reality, shows pitfalls in the way of changes and confronts the management with the opinions of the 'work floor'. The organization consultant in contrast, presents a route to the new desired organizational culture. The presentation concerns the desired solutions, the management perspective and, the resistance of the 'work floor'.

In summary, the business anthropologist makes, according to Olila and Teunissen (1989), a film of the organizational culture rather than a photo. The film concerns the cultural process in an organization and is in sympathy with the employees rather than with the management. The organization consultant, in contrast, makes a photo that gives a static image of the organizational culture. The photo is made from an outsider's perspective and is framed to suit the purposes and needs of the management.

\section{THE DISSIDENT COMMUNITY OF BUSINESS ANTHROPOLOGY}

Bate (1997) voices his frustration, claiming that organizational anthropologists' studies are never focused on the 'organizational' but on marginal groups such as football hooligans, cocktail servers, girl scouts or punks. So, even when Western society is the topic of study, anthropologists tend to study eccentric sub-cultures and marginal groups such as hooligans, girl scouts, punks and dance companies or the like (Bate 1997). For example, Moore's book (1997) The Future of Anthropological Knowledge the exploration of new fields of anthropological research in the contemporary Western society prefers the local and the periphery. Bate (1997) explains the lack of interest for true business anthropology because it takes too much time, it results in lengthy articles which are difficult to publish, and it takes the researcher away from the academic scene.

The advent of the new concept of organizational culture provided an excellent opportunity to contribute to the field of organizational studies. Indeed, other academic disciplines have embraced anthropological theoretical concepts and field research methodologies of participant observation for organizational culture research. However, with the exception of earlier mentioned European pioneers, anthropologists have in their typically recalcitrant and critical way shown little interest in helping business organizations in cultural issues (Jordan, 2003). Ethnographers are uncomfortable with business organizations. In his book Les tristes des tropics, Levi-Strauss (1955) suggests that the character of the anthropologist can explain ethnographers' 
lack of interest in Western management problems. Anthropologists are ill at ease in their own society but devoted to exotic cultures. They choose to play the role of observer in order to distance themselves from their own society. The ethnographer is therefore 'halfway' between the exotic and his own society (Levi-Strauss, 1966, p.432). It would run counter to his nature to come back and study his own society with the same enthusiasm as tribal societies. In his own society, the ethnographer is critical, recalcitrant - in short, a rebel.

\section{FUTURE DIRECTIONS IN EUROPE}

What are you doing here with Philips, mister Koot? Anthropologists, aren't they researchers of strange cultures and exotic rituals? Weird people, who travel to the jungle with backpack and an axe to study people living in primitive conditions (Koot, 1995, p.vii)?

This was the response of the head of the Philips human resource department where Willem Koot did his first organization cultural research in the early 1980s. In 1995, Philips put an advertisement for anthropologists to execute consumer behavior research with the department of Corporate Design. This was a shock for most Dutch anthropologists. Prud'homme (2005) compared the entry of anthropologists with the entry of the first physical scientist in 1914 into Philips. He hoped that the new anthropologists could follow in the footsteps of the physical pioneers in Philips and create new jobs. Indeed, thirty years after the start of the fourth period, European anthropologists do work in business organizations.

Business anthropology can be involved in a number of interesting commercial fields in Europe. However, anthropologists have to be encouraged to become involved in the field of organization studies. They should not be afraid to help business organizations that are confronted with new questions of cultural change, identification, diversity, and cross-cultural cooperation (Prud'homme, 2005). They have to present their capacities and learn to work in multidisciplinary teams. Then gatekeepers to organizational fields than better understand anthropologists' contributions to the organization.

The anthropologist can contribute to the organization studied in many different roles; the intercultural specialist, the organizational culture specialist, the interim manager, and the change management specialist (Olila and Teunissen, 1989). Giovannini and Rosansky (1990) advise the would-be business anthropologist to learn the client's language and business. But most importantly, anthropologists need self-confidence when entering organizations. Jordan states, with a touch of self-confidence:

We, as anthropologists, are able to apply our holistic, analytical techniques to describing the themes and compelling forces that support or diminish the welcoming of multiple perspectives. (Jordan, 1994, p.21).

The continuous change of private and public organizations in infrastructure, education, welfare, health care, sports, etc. is an interesting field of research. Changing perspectives on the state's role as well as changing expectations of clients and new ideas on service have forced organizations to change their culture. Over the last few decades, organizations in the rail-, road-, electricity-, gas-, and telecom-infrastructure, for example, have been confronted with radical changes worldwide. A wave of free market competition, liberalization, privatization, and 
deregulation has spread all over the world. Much academic attention is given to the consequences of these changes for the economy, technology, and public values. However, the organization cultural changes in the organizations involved, are understudied. Organizations have to adapt to processes of globalization (bringing in more competition), individualization (different customer demands and social context) and expansion of ICT applications (fast interaction, distinct service technologies, separation of space and time). The mutual effect of paradoxical developments and meanings results in an area of tension for organizations in which traditional, one-dimensional solutions fall short. Expectations towards market discipline, consumer values, competition, and autonomous status are largely based on mechanistic economical models and do not take cultural developments into account. Paying more attention to sense-making processes of customers and employees apart from the existing focus on the management perspective could, with anthropological methods such as observations and narrative analysis, bring more depth and control to processes of change.

Another interesting field is the field of international business relations and business networks. Due to processes of internationalization and globalization organizations are increasingly structured in intra-organizational networks. The reflexive process of identity construction is of importance as these networks consist of unstable cross-cultural strategic alliances. Organizations can be transnational as they include distinct nations and cross borders. Ethnic identity is an important organizing principle in the business networks (e.g. Dahles, 2004). The hybrid nature of these networks brings along new questions of inter- and intra-organizational cooperation. Literature on organizational cooperation in business networks is generally static and lacks a dynamic perspective. An anthropological perspective on inter- and intra-organizational cooperation, which includes power, cultural fragmentation, ambiguity, and complexity, can provide a better understanding of this expanding field of research.

Reviewing the ambitions of this article, I have been able to give a short overview of the development of organizational anthropology in Europe and in particular in the Netherlands. Business anthropology in the different fields of management of diversity, cultural change, crosscultural cooperation, organization culture, and organizational ethnography is alive in Europe. Not in a central position in the organization studies debate, but recognized by colleague scientists. Interesting research in contemporary multinational organizations and international business lies ahead of us. It would be a pity not to seize that opportunity.

\section{ENDNOTES}

Parts of the text on Dutch developments have been published in Van Marrewijk, A. H., \& Verweel, P. (2005). Exploring organisations. The development of organisational anthropology in the Netherlands. Amsterdam: SWP Publishers.

\section{REFERENCES}

Baba, M. L. (2001). Uniting Theory and Practice in American Corporations. Napa American Anthropological Association

Barth, F. (1969). Ethnic groups and boundaries: the social organisation of cultural difference. Sydney: Allen and Unwin. 
Bate, P. (1994). Strategies for Cultural Change. Oxford: Butterworth Heinemann.

Bate, P. (1997). Whatever Happened to Organizational Anthropology? A Review of the Field of Organizational Ethnography and Anthropological Studies. Human Relations, 50(9). 1147-1171.

Berg, P. O., \& Kreiner, K. (1990). Corporate architecture. In P. Gagliardi (Ed.), Symbols and artifacts (pp 124-145). New York: Aldine de Gruyter.

Chanlat, J. F. (1994). Francophone Organizational Analysis (1950-1990): An Overview. Organization Studies, 15(1). 47-80.

Chanlat, J. F. (1994). Towards an anthropology of organisations. In J. Hassard \& M. Parker (Eds.), Towards a New Theory of Organisations (pp 155-190). London: Routledge.

Chapman, M. (2001). Social Anthropology and Business Studies; Some Considerations of Method. In D. Gellner \& E. Hirsch (Eds.), Inside Organizations. Anthropologists at work. Oxford: Berg

Cohen, M., \& Sarphatie, E. (2007). Gezocht: Antropoloog m/v [Wanted: Anthropologist male/female]. Amsterdam: Aksant.

Corbett, S. (2008). Can the Cellphone Help End Global Poverty? New York Times Magazine. April $13^{\text {th }}$.

Czarniawska, B. (1992). Exploring Complex Organizations. A Cultural Perspective, London: Sage.

Czarniawska, B. (1998). A Narrative Approach to Organization Studies. London: Sage.

Dahles, H. (2004). Mc Business versus Confucius? Anthropological perspectives on transnational organizations and networks. (Vol. Inaugural speech). Amsterdam: VU Amsterdam.

Davenport, T. (2007). The rise of corporate anthropology, Harvard Business Review. November.

De Ronde, K. (2009). Op zoek naar de ziel van de consument [In search of the consumer's soul]. De Volkskrant. 13th of January

Deal, T. E., \& Kennedy, A. (1988). Corporate Cultures: the Rites and Rituals of Corporate Life. London: Penguin $\backslash$ Addison Wesley.

Dobbinga, E. (2000). Weerbarstigheid van organisatiecultuur. Een organisatie-antropologische studie naar betekenisgeving aan moderne management instrumenten [Stubbornness of organizational culture. An organization anthropological study on meaning making of modern management instruments]. VU University Amsterdam, Amsterdam. 
Fine, G. A., Morrill, C., \& Surianarain, S. (2008). Ethnography in organisation settings. In D. Buchanan \& A. Bryman (Eds.), Handbook of Organizational Research Methods. London: Sage.

Gagliardi, P. (1990). Symbols and artifacts. Views of the Corporate Landscape. New York: Walter de Gruyter.

Giovannini, M., \& Rosansky, L. M. H. (1990). Anthropology and Management Consulting: Forging a New Alliance. (Vol. 9): American Anthropological Association.

Gruener, W. (2004). When cultures shape technology. Tom's Hardware Guide. July $8^{\text {th }}$.

Hannerz, U. (1992). Cultural Complexity. Studies in the Social Organization of Meaning. New York: Columbia University Press.

Hannerz, U. (2010). Anthropology's World. Life in a Twenty-First-Century Discipline. London: PlutoPress.

Hofstede, G. (1980). Culture's Consequences: International Differences in Work-Related Values. London: Sage Publications.

Hofstede, G. (1986). The usefulness of the 'Organizational Culture' concept. Journal of Management studies 23(3), 253 - 257.

Holzberg, C. S., \& Giovannini, M. (1981). Anthropology and Industry: Reappraisal and New Directions. Annual Review of Anthropology(10), 317-360.

Jordan, A. (1994). Practicing Anthropology in Corporate America: Consulting on Organization Culture. (Vol. 14): American Anthropological Association.

Jordan, A. (2003). Business Anthropology. Prospect Heights, Illinois: Waveland Publishers.

Koot, W. (1989). Organisatieantropologie in Nederland: een belangwekkend nieuw studieveld? [Business Anthropology in the Netherlands: an interesting new field?] Antropologische Verkenningen, 8(4), 1-11.

Koot, W. (1995), De complexiteit van het alledaagse. Een antropologisch perspectief op organisaties [Complexity of everyday life. An anthropological perspective of organizations], Busssum: Coutinho.

Koot, W. (1997). Strategic Utilization of Ethnicity in Contemporary Organizations. In S. Sackmann (Ed.), Cultural Complexity in Organisations; Inherent Contrast and Contradictions, (pp 315 - 339). California: Sage Publications.

Koot, W., \& Boessenkool, J. (1994). De cultuur van een arbeidsorganisatie: theoretisch uitdagend, voor onderzoekers een ramp ! [The culture of organizations. Theoretical challenging, to researchers a disaster!] Antropologische Verkenningen, 13(2), 54-69. 
Koot, W., \& Hogema, I. (1990), Organisatiecultuur. Fictie en werkelijkheid [Corporate culture. Fiction and reality], Muiderberg: Coutinho.

Koot, W., Sabelis, I., \& Ybema, S. (Eds.). (1996), Contradictions in Context. Puzzling over paradoxes in contempory organizations. Amsterdam: VU University Press.

Koot, W., Staartman, M., \& Verbeek, J. (1989), Myten over corporate culture, fictie en werkelijkheid van organisatiecultuur in de profit en non-profitsector [ Myths over corporate culture. Fiction and reality of organization culture in profit and nonprofit sector], Utrecht: Rijksuniversiteit Utrecht.

Kunda, G. (1992), Engineering culture : control and commitment in a high-tech corporation, Philadelphia: Temple University Press.

Latour, B. (1987), Science in Action: How to Follow Scientists and Engineers Through Society, Milton Keynes: Open University Press.

Latour, B. (1993), We have never been modern London: Harvester Wheatsheaf.

Lévi-Strauss, C. (1955), Tristes Tropiques, Paris: Plon.

Lévi-Strauss, C. (1966), The savage mind, Chicago: University of Chicago Press.

Lowe, S. (2002). The Cultural Shadows of Cross Cultural Research: Images of Culture. Culture and Organisation, 8(1), 21-34.

Miller, B. (2005). Anthropology and business come together. Small business bulletins. November.

Morden, T. (1999). Models of National Culture - Management Review. Cross Cultural Management, 6(1), 19-44.

Nicholson, T. (1994). Institutional building: examining the fit between bureaucracies and indigenous systems. In S. Wright (Ed.), Anthropology of organizations. London: Routledge.

Olila, J., \& Teunissen, I. (1989). Wie ben ik dat ik dit durf? De antropoloog als organisatieadviseur. Antropologische Verkenningen, 8(4), 1-18.

Pant, D., \& Alberti, F. (1997). Anthropology and business: reflections on the business applications of cultural anthropology, Serie Economica e Impresea 11, Liuc Papers nr.42.

Parker, M. (2000), Organizational culture and identity: unity and division at work, London: Sage.

Peters, T. J., \& Waterman, R. H. (1982), In search of excellence : lessons from America's bestrun companies, New York; London: Harper and Row. 
Prud'homme, P. (2005). Love is in the air, but what about the struggles for power on the ground? The 'naive' organization anthropologist in the world of strategic cross-border cooperation. In A. H. Van Marrewijk \& P. Verweel (Eds.), Exploring Organisations. The Development of Organisational Anthropology in the Netherlands. Utrecht: SWP.

Sabelis, I. (2002). Managers Times. A study of time in the work and life of top managers. Amsterdam: VU University Press.

Sanders, G., \& Nueijen, B. (1989), Bedrijfsculturen in kaart gebracht' in: Organisatiediagnose. Theorie en praktijk [Mapping organizational culture in organizational diagnose: Theory and practice], Leiden: Spruyt.

Schein, E. H. (1985), Organizational Culture and Leadership, San Francisco: Jossey Bass.

Schwartzman, H. B. (1993), Ethnography in Organizations (Vol. 27), Newbury Park: Sage Publications, Inc.

Serrie, H. (1984), Anthropology and International Business (Vol. 28), Williamsburg: College of William and Mary.

Tennekes, H. (1994). Cultuur en handelen: perspectieven voor een antropologische cultuurtheorie [Culture and behavior: perspectives of an anthropological theory of culture]. Antropologische verkenningen: De dynamiek van cultuur, 13(2), 1-16.

Tennekes, J. (1995), Organisatiecultuur: een antropologische visie [Organizational culture: an anthropological perspective], Leuven/Apeldoorn: Garant.

Tett, G. (2005). Office culture. Financial Times. $20^{\text {th }}$ May.

Trompenaars, F. (1993), Riding the waves of Culture. Understanding cultural diversity in business, London: The Economist Books Ltd.

Van Marrewijk, A. H. (1999), Internationalization, Cooperation and Ethnicity in the Telecom Sector. An Ethnographic Study of the Cross-cultural Cooperation of KPN in Unisource, The Netherlands Antilles and Indonesia. Delft: Eburon.

Van Marrewijk, A. H., Veenswijk, M., \& Clegg, S. R. (2010). Organizing reflexivity in designed change; the ethnoventionist approach. Journal of Organizational Change Management, 23(3), 212-229.

Van Marrewijk, A. H., \& Verweel, P. (2005), Exploring organizations. The development of organizational anthropology in the Netherlands, Amsterdam: SWP publishers.

Verweel, P. (1989). Het antropologisch instrumentarium [Anthropological instruments]. Antropologische verkenningen: Totems en stropdassen, antropologen over cultuur en management, 13(4), 22-39. 
Watson, T. (1994), In search of managment: culture, chaos \& control in managerial work, London: International Thomson Business Press.

Weick, K. E. (1995), Sensemaking in Organizations, London: Sage.

Wels, H. (2000). Wels, H. (2000). Fighting over fences. Organizational co-operation and reciprocal exchange between the Savé Valley Conservancy and its neighbouring communities. Dissertation, Vrije Universiteit Amsterdam., Amsterdam: VU University Press.

Wright, S. (1994), Anthropology of organizations, London: Routledge.

Yanow, D., \& Geuijen, K. (2009). Annotated bibliography. Defining 'organizational ethnography' selection criteria. In S. Ybema, D. Yanow, H. Wels \& F. Kamsteeg (Eds.), Organizational Ethnography. Studying he Complexities of Everyday Life. London: Sage.

Ybema, S. (2003). De koers van de krant. Vertogen over identiteit bij Trouw en de Volkskrant. Amsterdam: VU University Press.

Ybema, S., Yanow, D., Wels, H., \& Kamsteeg, F. (2009), Organizational Ethnography. Studying the Complexities of Everyday Life, London: Sage. 